Jurnal Penelitian dan Evaluasi Pendidikan

198 - Jurnal Penelitian dan Evaluasi Pendidikan Tahun 17, Nomor 2, 2013 


\title{
MODEL EVALUASI PROGRAM TUTORIAL TATAP MUKA UNIVERSITAS TERBUKA
}

\author{
1) Adi Suryanto, 2) Abdul Gafur, 3)FX. Sudarsono \\ 1)FKIP-Universitas Terbuka, 2, 3)Universitas Negeri Yogyakarta \\ 1)adis@ut.ac.id, 2)agafur68@gmail.com, 3)fxsudarsono@uny.ac.id
}

\begin{abstract}
Abstrak
Penelitian ini bertujuan untuk mengembangkan model evaluasi program tutorial tatap muka. Model evaluasi yang dikembangkan dalam penelitian ini menekankan pada evaluasi: perencanaan, pelaksanaan, dan hasil program tutorial sehingga model ini disebut model evaluasi P2HT. Model evaluasi P2HT dikembangkan melalui delapan tahap: (1) kajian awal, (2) pengembangan disain, (3) pengembangan model prototype, (4) uji coba terbatas, (5) revisi, (6) uji coba diperluas, (7) model akhir, dan (8) diseminasi. Model prototype diuji coba di UPBJJ-UT Yogyakarta dalam tiga tahap yaitu uji coba tahap 1, 2, dan 3. Validitas model dan perangkat model ditetapkan melalui uji keterbacaan, validasi isi dan validasi konstruk. Uji keterbacaan dilakukan oleh 15 ahli, 12 praktisi pendidikan jarak jauh, dan 55 mahasiswa. Validitas isi dibuktikan dengan mendiskusikan model dan perangkat model dengan para ahli melalui diskusi secara langsung dengan ahli, pendapat ahli melalui email, dan dikusi melalui forum FGD. Validasi konstruk dibuktikan dengan menggunakan Confirmatory Factor Analysis dan Exploratory Factor Analysis. Estimasi reliabilitas dilakukan dengan formula Alpha per dimensi. Path analysis digunakan untuk menguji hubungan kausal antar variabel yang ada dalam model evaluasi P2HT. Hasil penelitian ini menunjukkan bahwa: (1) model evaluasi P2HT merupakan model yang komprehensif, tepat, praktis, mudah digunakan dan mempunyai tingkat keterbacaan yang tinggi, (2) semua instrumen yang dihasilkan memenuhi persyaratan validitas dan reliabilitas, (3) pengelolaan program, kemandirian mahasiswa dalam belajar, tempat/fasilitas, proses tutorial, dan kepuasan mahasiswa berpengaruh terhadap hasil belajar. Dari kelima variabel tersebut, proses tutorial memberikan pengaruh terbesar terhadap hasil belajar mahasiswa dengan total pengaruh sebesar 58\%.
\end{abstract}

Kata kunci: model evaluasi, tutorial tatap muka, instrumen, validitas dan reliabilitas.

\section{AN EVALUATION MODEL OF FACE-TO-FACE TUTORIAL PROGRAM OF THE OPEN UNIVERSITY}

This study aims at developing an evaluation model of the face-to-face tutorial program implemented by the Open University. The model of evaluation developed in this research focuses on evaluation of: planning, processing, and results, so the model is called the P2HT evaluation model. The P2HT evaluation model is developed on eight steps: (1) preliminary research, (2) designing model, (3) developing prototype model, (4) trying-out with limited number of samples, (5) revising, (6) trying-out with larger samples, (7) constructing final model, and (8) disseminating. The prototype model was tried-out at Yogyakarta Open University Regional Center in three stages. The readability was tested to 15 experts, 12 practitioners, and 55 students. The content validity was measured by a series of discussion forum involving evaluation experts and distance education experts, in the form of face-to-face meetings, FGDs, as well as emails. The construct validity was analyzed by using Confirmatory Factor Analysis and Exploratory Factor Analysis, while the reliability was analyzed for each dimension employing the Alpha analysis per dimention. The path analysis was used to analyze the causality relationship among variables in the P2HT evaluation model especially in stage 3 try-out. The results of the study indicate that: (1) the P2HT evaluation model is comprehensive, valid, practical, easy to use, and has a high level of readability, (2) all instruments are valid and reliable, (3) the management of program, self-directed learning, place and facilities of tutorial, tutorial process, and students' satisfaction have an effect on the students' achievement. Among the five variables, the process of tutorial has given the greatest effect $58 \%$.

Keywords: evaluation model, face-to-face tutorial, instrument, validity and reliability 


\section{Pendahuluan}

Program tutorial merupakan program layanan bantuan belajar akademik yang diberikan oleh seseorang kepada orang lain dalam mengembangkan cognitive skills, knowledge, and learning skills (Ormond, 2000, pp.6-7). Peraturan Menteri Pendidikan dan Kebudayaan nomor: 24 tahun 2012 tentang Penyelenggaraan Pendidikan Jarak Jauh pada Pendidikan Tinggi Pasal 1 Ayat 4 menyatakan bahwa tutorial adalah bentuk bantuan belajar akademik yang dapat dilaksanakan secara tatap muka maupun melalui pemanfaatan teknologi informasi dan komunikasi (Depdikbud, 2012). Di samping sebagai program layanan bantuan belajar, program tutorial juga merupakan program pembelajaran karena program tutorial bertujuan untuk membantu mahasiswa mencapai tujuan belajar yang telah ditentukan. Holmberg (2005, p.104) menjelaskan bahwa tujuan tutorial dalam pendidikan jarak jauh adalah untuk: (1) Mendorong minat dan motivasi peserta didik melalui kontak dengan tutor dan konselor, (2) Mendorong dan memfasilitasi pembelajaran peserta didik dalam menerapkan pengetahuan dan keterampilan untuk menyelesaikan tugas dimana tugas tersebut dicek, didiskusikan dengan tutor serta diperbaiki berdasarkan umpan balik dan komentar yang diberikan tutor, (3) Memberi kesempatan kepada setiap peserta didik untuk mengembangkan kemampuan berfikir, (4) Untuk mengukur kemajuan belajar setiap peserta didik.

Tutorial tatap muka merupakan jenis layanan bantuan belajar yang paling banyak diikuti oleh mahasiswa UT. Layanan ini banyak dimanfaatkan oleh mahasiswa khususnya mereka yang mengalami kesulitan dalam memahami bahan ajar secara mandiri, mereka memerlukan kehadiran tutor untuk membantu memahami bahan ajar (Wardani, 2000). Pendapat tersebut sesuai dengan hasil penelitian Kadarko (2000), Adji (2009), hasil wawancara wartawan Harian Kedaulatan Rakyat dengan mahasiswa Non-Pendas, dan hasil wawancara peneliti dengan mahasiswa Pendas UPBJJ-UT Surakarta.
Menurut Subagja (2001, pp.245-246) rendahnya kemandirian mahasiswa UT dalam belajar mandiri berhubungan dengan kebiasaan atau budaya belajar yang selama ini dilakukan oleh mahasiswa. Budaya belajar di Indonesia belum mendukung tumbuhnya belajar mandiri. Hal ini terkait dengan sistem pembelajaran formal yang selama ini dijalani oleh masyarakat Indonesia yaitu belajar tatap muka. Hasil penelitian menunjukkan bahwa kemandirian mahasiswa dalam belajar berkorelasi positif dengan hasil belajar (Darmayanti, 1993; Islam, 2000; dan Tahar \& Enceng, 2006). Belawati (1997) menemukan bahwa ketidaksiapan mahasiswa UT untuk belajar mandiri berdampak pada rendahnya prestasi hasil belajar dan tingginya angka mahasiswa yang tidak menyelesaikan studi dengan tingkat persistensi rendah.

Mengingat penting dan strategisnya peran tutorial tatap muka bagi UT untuk membantu mahasiswa UT yang mengalami kesulitan belajar maka kualitas tutorial harus selalu ditingkatkan dari waktu ke waktu. Cara terbaik untuk meningkatkan kualitas program tutorial tatap muka UT adalah dengan melakukan evaluasi secara terus menerus terhadap program tersebut.

Untuk mengembangkan model evaluasi tutorial tatap muka yang tepat diperlukan kajian teori tentang karakteristik program dan analisis komponen program. Penjelasan karakteristik program dan analisis komponen diperlukan untuk menentukan model evaluasi yang akan digunakan sebagai dasar dalam mengembangkan model evaluasi tersebut (Gall, Gall, \& Borg, 2003, p.546). Program tutorial tatap muka UT dapat dipandang sebagai program layanan bantuan belajar dan sebagai program pembelajaran. Sebagai program layanan bantuan belajar maka program tutorial tatap muka UT harus berorientasi pada kepuasan pelanggan (Gerson, 1993, p.5) dan sebagai program pembelajaran maka program tutorial tatap muka UT harus dapat memfasilitasi mahasiswa dalam mengkonstruksi pengetahuannya (Reigeluth \& Carr-Chellman (2009, p.6). Agar program pembelajaran dapat berlangsung efektif maka program pembelajaran 
perlu dirancang, dikembangkan, dilaksanakan, dan dievaluasi dengan baik (Dick, Carey, \& Dick, 2005, p.3).

Berdasarkan karakteristik program tutorial tatap muka UT. terdapat tiga komponen program yang perlu mendapat perhatian dalam mengevaluasi program tersebut yaitu: perencanaan, pelaksanaan, dan hasil program. Ketiga komponen program inilah yang akan menjadi fokus dalam mengembangkan model evaluasi program tutorial tatap muka UT sehingga model evaluasi ini dinamakan model evaluasi P2HT (model evaluasi Perencanaan, Pelaksanaan, dan Hasil Tutorial). Evaluasi komponen perencanaan akan difokuskan pada aspek: (1) pengelolaan program, (2) kemandirian mahasiswa dalam belajar, dan (3) tempat/fasilitas tutorial. Evaluasi pelaksanaan program difokuskan pada aspek kualitas proses tutorial dan evaluasi hasil program difokuskan pada aspek kepuasan mahasiswa dan hasil belajar.

Menurut Johnson, Kast, \& Rosenzweig (1973, pp.15-16) pengelolaan merupakan serangkaian kegiatan yang berfokus pada kegiatan untuk menggerakkan: perencanaan, pengorganisasian, dan pengawasan untuk mencapai tujuan. Dalam mengelola program tutorial tatap muka, pengelola perlu menggerakkan kegiatan perencanaan program seperti: mendata jumlah mahasiswa peserta tutorial, merencanakan jumlah tutor yang diperlukan, menyeleksi dan melatih tutor, menentukan tempat/fasilitas tutorial yang memadai, mempersiapkan perangkat pelaksanaan tutorial (bahan ajar, rancangan acara tutorial, satuan acara tutorial, jadwal tutorial, daftar hadir), menggerakkan proses tutorial, dan mengawasi pelaksanaan proses tutorial. Agar proses tutorial dapat berlangsung secara efektif, pengelola perlu mengetahui tingkat kemandirian mahasiswa dalam belajar karena informasi tersebut sangat dibutuhkan oleh tutor untuk menentukan strategi tutorial yang tepat. Grow (1991) menyatakan bahwa untuk mengajar murid dengan tingkat kemandirian belajar tertentu diperlukan strategi pembelajaran yang tertentu pula. Tutor yang berkualitas, tempat/ fasilitas tutorial yang memadai, dan adanya informasi yang tepat tentang kemandirian mahasiswa dalam belajar akan menentukan kualitas proses tutorial. Penyediaan support system dan pengelolaan program yang baik akan mendorong kemandirian mahasiswa dalam (Long, 1990, p.37), mahasiswa akan merasa puas (Gerson, 1993, p.5), mahasiswa dapat belajar lebih efektif sehingga hasil belajar akan meningkat (Melton, 2002, p.110).

Berdasarkan kajian teori berbagai model evaluasi program, model evaluasi program pelatihan Kirkpatrick (Kirkpatrik \& Kirkpatrick, 2006, p.3) dan model evaluasi Alkin (Fitzpatrick, Sanders, \& Worthen, 2004, p.92) merupakan dua model evaluasi yang dapat digunakan sebagai dasar dalam pengembangan model evaluasi program tutorial tatap muka UT. Dalam mengevaluasi suatu program pelatihan, Kirkpatrick \& Kirkpatrick (2006, p.21) menekankan pada empat level evaluasi yaitu: (1) evaluasi level 1 yaitu evaluasi reaksi peserta terhadap pelaksanaan program pelatihan (reaction leve), (2) evaluasi level 2 yaitu evaluasi terhadap peserta setelah mengikuti program pelatihan (learning leve), (3) evaluasi level 3 yaitu evaluasi terhadap perilaku peserta setelah kembali ke tempat kerja (behavior level).dan evaluasi level 4 yaitu evaluasi terhadap hasil yang diperoleh institusi atau perusahaan setelah peserta yang dikirim untuk mengikuti pelatihan kembali ke tempat kerja (result level).

Alkin (Fitzpatrick, Sanders, \& Worthen, 2004, p.92) mengevaluasi program dalam lima tahap evaluasi: (1) System assessment. bertujuan untuk memberi informasi tentang keadaan sistem. Pada tahap ini akan dilakukan needs assessment. Adanya needs menunjukkan adanya gap antara apa yang ada dengan apa yang seharusnya ada. Adanya gap menunjukkan adanya masalah. Selanjutnya, masalah yang ada akan digunakan untuk menentukan tujuan program, (2) Program planning: membantu memilih program-program yang efektif untuk memenuhi needs yang teridentifikasi dari system assessment. Menurut Kaufman \& Thomas (1980, p.119), fokus pada tahap ini adalah pada pembuatan perencanaan program untuk memenuhi kebutuhan yang teridentifikasi pada tahap pertama, (3) Program implementation: memberikan 
informasi apakah program telah dilaksanakan dengan tepat sesuai dengan rencana, (4) Program improvement. Issue utama pada tahap ini adalah seberapa besar program dapat mencapai tujuan dengan perhatian utama diberikan pada produk yang dikembangkan, dan (5) Program certification: memberikan informasi tentang pencapaian tujuan program secara keseluruhan dan informasi tentang potensi dari program tersebut untuk digunakan di tempat lain.

Pertimbangan pemilihan kedua model tersebut sebagai dasar pengembangan model evaluasi P2HT adalah Program pelatihan dan program tutorial tatap muka merupakan program layanan yang berorientasi pada kepuasan pelanggan dan hasil belajar. Dalam model evaluasi P2HT, model evaluasi pelatihan Kirkpatrick tampak pada evaluasi kepuasan pelanggan (evaluasi level 1) dan evaluasi hasil belajar (evaluasi level 2), sedangkan model evaluasi Alkin tampak pada evaluasi perencanaan (program planning), evaluasi pelaksanaan (program implementation), dan evaluasi hasil (program certification). Secara konseptual model evaluasi P2HT dapat digambarkan sebagai berikut.

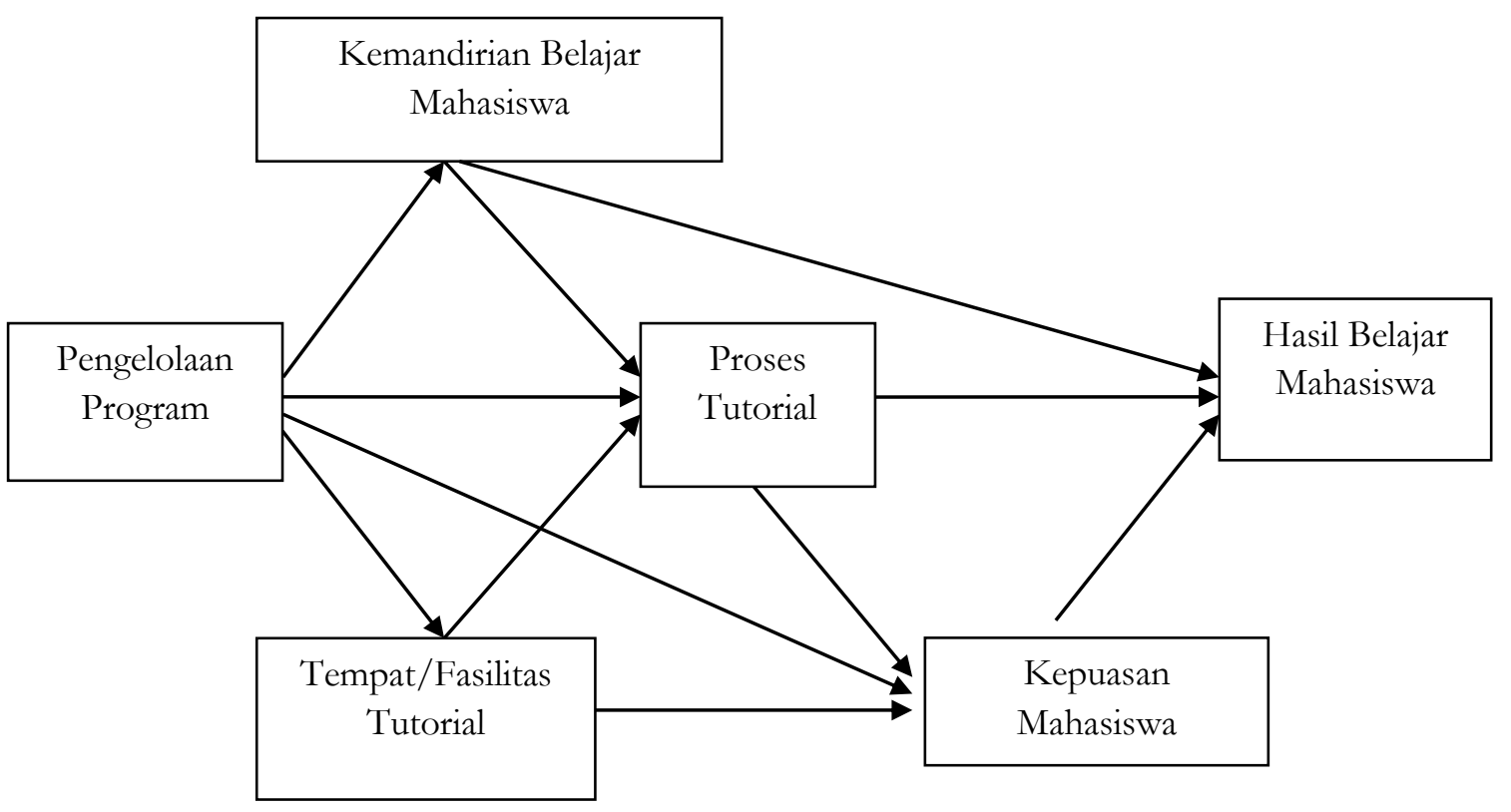

Gambar 1. Bagan Model Konseptual Evaluasi P2HT

Beberapa hasil penelitian yang berhubungan dengan program tutorial tatap muka telah dilakukan oleh beberapa peneliti antara lain: Sudilah, Astuti, \& Zuhriyah (2009) yang menemukan bahwa pengelolaan tutorial tatap muka mahasiswa program Pendas berjalan dengan baik. Hal ini dibuktikan dengan adanya perencanaan program tutorial yang baik, pelaksanaan tutorial yang lancar, layanan terhadap mahasiswa, tutor, dan pengurus pokjar yang baik serta adanya supervisi dan monitoring yang dilaksanakan secara kontinu. Adji (2009) yang melakukan penelitian tentang analisis kepuasan mahasiswa pada kegiatan tutorial tatap muka mata kuliah Praktikum IPA SD menemukan bahwa keberadaan tutorial tatap muka sangat dibutuhkan oleh mahasiswa UT. Kehadiran tutor sangat diperlukan mahasiswa untuk membantu mengatasi kesulitan belajar yang mereka alami. Keterlibatan mahasiswa dalam tutorial termasuk tinggi, materi tutorial, sarana dan prasarana tutorial dinilai baik oleh mahasiswa. Amini, Mardiana, \& Hanafi (2009) dalam meneliti tentang efektivitas pelaksanaan bimbingan pada mata kuliah Pemantapan Kemampuan Mengajar (PKM) menyimpulkan bahwa pembimbingan berja- 
lan kurang efektif. Hasil penelitian yang tidak jauh berbeda diperoleh Chandrawati, Tatminingsih, \& Budiastra (2009) yang meneliti efektivitas pelaksanaan bimbingan mata kuliah Peningkatan Kemampuan Profesional (PKP) pada mahasiswa S1 PGPAUD di UPBJJ-UT Jakarta, Denpasar, dan Serang. Suharno, Supoyo, \& Suparno (2009) yang mengkaji faktor-faktor pelaksanaan program tutorial mahasiswa S1 PGSD UPBJJ-UT Bandar Lampung menemukan bahwa masih ada tutor yang mengalami hambatan dalam membuat persiapan tutorial, fasilitas tutorial yang berupa media pembelajaran untuk melaksanakan tutorial dinilai kurang oleh mahasiswa, pendekatan pembelajaran dalam tutorial yang dilakukan tutor dinilai cukup baik oleh mahasiswa, dalam tutorial mahasiswa cukup aktif, hasil belajar mahasiswa untuk mata kuliah yang diikuti tutorialnya lebih baik dari nilai mata kuliah yang tidak diikuti tutorialnya, dan ahasiswa merasa puas dalam mengikuti tutorial. Kadarko (2000) yang meneliti kemampuan belajar mandiri dan faktor-faktor psikososial yang mempengaruhinya pada mahasiswa Universitas Terbuka menemukan bahwa kemampuan belajar mahasiswa Universitas Terbuka masih rendah. Mahasiswa masih mempertahankan perilaku belajar tradisional berbasis kampus, mahasiswa masih menghendaki adanya pertemuan tatap muka dengan dosen dan masih mempunyai keinginan yang kuat untuk saling berinteraksi dengan mahasiswa lain. Sebagai akibat dari adanya hambatan tersebut maka kesulitan dalam memahami bahan ajar masih merupakan kendala utama mahasiswa Universitas terbuka. Belawati (1997) juga menemukan bahwa ketidaksiapan mahasiswa untuk belajar mandiri berdampak pada rendahnya prestasi hasil belajar dan tingginya angka mahasiswa yang tidak menyelesaikan studi dengan tingkat persistensi yang rendah.

Zirkle (2004) mengidentifikasi hambatan-hambatan dalam pelaksanaan pendidikan jarak jauh yang meliputi: (1) hambatan yang ada pada institusi penyelenggara antara lain: biaya program kurang, sumber daya yang kurang memadahi, kurangnya peralatan dan infrastruktur, dan kurangnya pelatihan; (2) hambatan yang ada pada mahasiswa antara lain: rendahnya motivasi, kurangnya umpan balik dan kontak dengan instruktur, keterasingan mahasiswa karena tidak tatap muka, kurangnya layanan bantuan mahasiswa, dan kurangnya pengalaman mahasiswa dengan sistem belajar jarak jauh. Zhang \& Fulford (1994) dan Zirkin \& Sumler (1995) yang meneliti tentang interaksi yang terjadi pada mahasiswa pendidikan jarak jauh menemukan bahwa kenaikan interaksi dalam pembelajaran dapat meningkatkan kepuasan dan hasil belajar mahasiswa. Panagiotis \& Chrysoula (2010) yang meneliti tentang komunikasi antara tutor dengan mahasiswa pendidikan jarak jauh menemukan bahwa komunikasi dua arah antara mahasiswa dengan tutor dalam kelompok belajar merupakan salah satu kunci keberhasilan mahasiswa dalam belajar di pendidikan jarak jauh. Interaksi langsung antara mahasiswa dengan tutor dalam kelompok belajar merupakan bentuk interaksi yang paling diminati oleh mahasiswa. Mereka menyatakan bahwa pertemuan tatap muka dengan tutor sangat membantu menjawab pertanyaan mahasiswa, membantu memahami materi yang sedang dipelajari, juga merupakan wahana untuk membangun komunikasi dengan tutor dan mahasiswa lain. Samarawickrama (2005, pp.49-67) yang meneliti tentang kesiapan mahasiswa dalam flexible learning menemukan bahwa mahasiswa belum siap dengan sistem tersebut, mereka sangat membutuhkan kehadiran dosen dan lingkungan kelas. Mereka menyatakan jika dosen tidak datang ke kelas mereka menjadi malas belajar dan akan menurunkan motivasi. Dosen diperlukan kehadirannya untuk memberikan teori dan informasi serta memberi masukkan atas tugas-tugas yang mereka kerjakan. Menjaga motivasi yang merupakan salah satu learning skills yang harus dimiliki mahasiswa telah diteliti oleh Visser (Richey \& Klein, 2007, pp.48-49). Visser menemukan bahwa serial pesan motivasi yang efektif ternyata dapat menurunkan angka drop-out mahasiswa dan dapat menurunkan angka rata-rata mahasiswa yang tidak menyelesaikan studi pada pendidikan jarak jauh. 
Permasalahan yang akan dicarikan solusinya dalam penelitian ini adalah: (1) Apakah model evaluasi program P2HT yang dihasilkan dalam pengembangan merupakan model tepat, komprehensif, praktis dan mudah digunakan, (2) Bagaimanakah hasil evaluasi program $\mathrm{P} 2 \mathrm{HT}$ ?

\section{Metode Penelitian}

Model penelitian pengembangan yang digunakan dalam penelitian ini mengikuti langkah inti penelitian pengembangan yang digunakan oleh beberapa ahli seperti: Gall, Gall, \& Borg (2003), Richey \& Klein (2007), Visser (Richey \& Klein, 2007), dan Peffers (2007). Tahapan penelitian pengembangan yang digunakan meliputi: (1) Kajian awal, (2) Penyusunan desain pengembangan, (3) Pengembangan produk awal (prototype), (4) Uji coba, (5) Revisi, (6) Produk akhir, dan (7) Diseminasi.

Kajian awal menunjukkan bahwa program tutorial tatap muka sangat diperlukan mahasiswa, mereka memerlukan kehadiran tutor untuk membantu memahami bahan ajar (Wardani, 2000). Pendapat tersebut sesuai dengan hasil penelitian Kadarko (2000), Adji (2009), hasil wawancara wartawan Harian Kedaulatan Rakyat dengan mahasiswa UT (Mahasiswa UT dituntut belajar mandiri, Kedaulatan Rakyat, 4 November 2010, p.18), dan hasil wawancara peneliti dengan mahasiswa Pendas UPBJJ-UT Surakarta bulan Agustus 2010. Program tutorial tatap muka belum pernah dievaluasi secara komprehensif. Kajian tentang program tutorial tatap muka dilakukan secara parsial seperti dilakukan oleh Sudilah, Astuti, \& Zuhriyah (2009), Adji (2009), Amini, Mardiana, \& Hanafi (2009), Suharno, Supoyo, \& Suparno (2009), Puspitasari \& Islam (2003), Julaeha (2002), Sugilar dan Isfarudi (2002), Sekarwinahyu \& Rahayu (2009), Sigit et.al. (2008). UPBJJ-UT sebagai penyelenggara program tutorial tatap muka di daerah tidak dapat melakukan evaluasi program secara komprehensif karena di UPBJJ-UT tidak tersedia perangkat evaluasi. UPBJJ-UT memerlukan perangkat untuk mengevaluasi program tutorial tatap muka.
Model evaluasi program tutorial yang dikembangkan adalah model evaluasi P2HT yang menekankan pada evaluasi: perencanaan, pelaksanaan, dan hasil tutorial. Evaluasi perencanaan difokuskan pada aspek: (1) pengelolaan program, (2) kemandirian mahasiswa dalam belajar, dan (3) tempat/fasilitas tutorial. Evaluasi pelaksanaan program difokuskan pada aspek kualitas proses tutorial dan evaluasi hasil program difokuskan pada aspek kepuasan mahasiswa dan hasil belajar. Model evaluasi P2HT dilengkapi dengan perangkat evaluasi yang terdiri dari: (1) Pedoman penyelenggaraan evaluasi, (2) Instrumen, dan (3) Format pelaporan hasil evaluasi. Instrumen yang dikembangkan terdiri dari: (1) Persepsi mahasiswa terhadap pengelolaan program tutorial, (2) Kemandirian mahasiswa dalam belajar, (3) Persepsi mahasiswa terhadap tempat/fasilitas tutorial, (4) Persepsi mahasiswa terhadap kualitas proses tutorial, (5) Kepuasan mahasiswa terhadap layanan program tutorial, dan (6) Format evaluasi hasil belajar mahasiswa. Untuk melaporkan hasil evaluasi dikembangkan: (1) Format pelaporan evaluasi perencanaan, (2) Format evaluasi pelaksanaan, dan Format evaluasi hasil tutorial.

Model prototype yang dihasilkan dalam penelitian ini diuji coba dalam tiga tahap. Uji coba tahap 1 dimaksudkan untuk memperoleh model prototype dan perangkat model yang valid dan reliabel. Uji coba tahap 2 merupakan uji coba model dan perangkat pada sampel terbatas (melibatkan 3 tutor dan 62 mahasiswa). Uji coba tahap 3 merupakan uji coba model dan perangkat model pada sampel diperluas (melibatkan 16 tutor dan 416 mahasiswa).

Validitas model dan reliabilitas perangkat dilakukan dengan meminta pendapat ahli evaluasi, ahli dan praktisi pendidikan jarak jauh, serta uji statistik. Confirmatory Factor Analysis (Ghozali \& Fuad, 2005, pp.29-32) dan Exploratory Factor Analysis (Hair et.al., 2010, pp.106-123) digunakan untuk menganalisis validitas instrumen. CFA digunakan untuk menganalisis dua instrumen yang pengembangan indikatornya didasarkan pada teori yang kuat yaitu 
persepsi mahasiswa terhadap pengelolaan program tutorial dan kemandirian mahasiswa dalam belajar. EFA digunakan untuk menganalisis tiga instrumen yang pengembangan indikatornya didasarkan pada pertimbangan (judgment) yaitu: persepsi mahasiswa terhadap tempat/fasilitas tutorial, persepsi mahasiswa terhadap kualitas proses tutorial, dan kepuasan mahasiswa terhadap layanan program tutorial. Reliabilitas instrumen dianalisis dengan menggunakan formula Alpha perdimensi dan dilanjutkan dengan menghitung estimasi reliabilitas kombinasi linier (Nunnally, 1978, p.246). Path analisis digunakan untuk memaknai hasil evaluasi program tutorial tatap muka yang dilakukan dengan menggunakan model evaluasi P2HT (Sarwono, 2012, pp.17-18).

\section{Hasil Penelitian dan Pembahasan}

Dari keseluruhan aspek penilaian model, para ahli dan praktisi pendidikan jarak jauh masing-masing memberikan nilai dalam kategori baik dengan skor rata-rata 3,5 dan 3,28 dari skor maksimal 4 untuk aspek kekomprehensifan model, ketepatan model, kepraktisan model, dan kemudahan penggunaan model. Dari keseluruhan aspek penilaian pedoman penyelenggaraan evaluasi, para ahli dan praktisi pendidikan jarak jauh masing-masing memberikan nilai dalam kategori baik dengan skor rata-rata 3,4 dan 3,3 dari skor maksimal 4 untuk aspek isi pedoman, bahasa yang digunakan, keterbacaan, dan kemudahan penggunaan. Untuk uji keterbacaan instrumen, penilai yang terdiri dari 15 ahli, 12 praktisi, dan 55 mahasiswa memberikan skor minimal 3,1 dari skor maksimal 4 untuk setiap aspek yang dinilai yang meliputi: kejelasan petunjuk, bahasa yang digunakan, keterbacaan, dan kemudahan penggunaan instrumen sehingga dapat dinyatakan bahwa instrumen mempunyai tingkat keterbacaan dalam kategori baik.
Hasil CFA untuk Kuesioner Kemandirian Mahasiswa dalam Belajar.

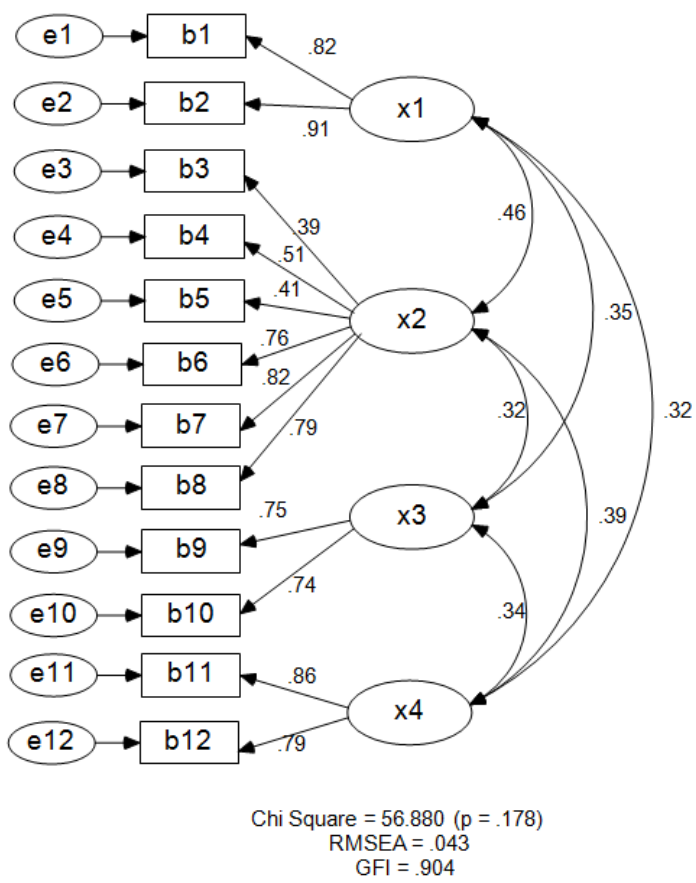

Gambar 2. Model CFA Kemandirian Mahasiswa dalam Belajar Hasil Uji Coba Tahap 1

Hasil CFA untuk instrumen persepsi mahasiswa terhadap pengelolaan program tutorial tatap muka.

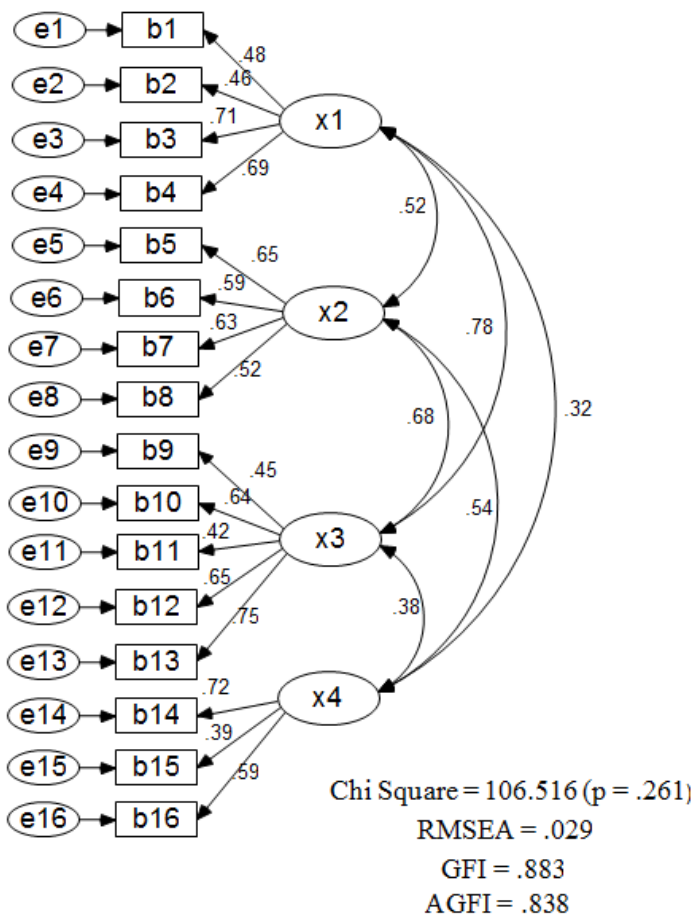

Gambar 3. Model CFA Persepsi Mahasiswa terhadap Pengelolaan Program Tutorial

Tatap Muka Hasil Uji Coba Tahap 1 


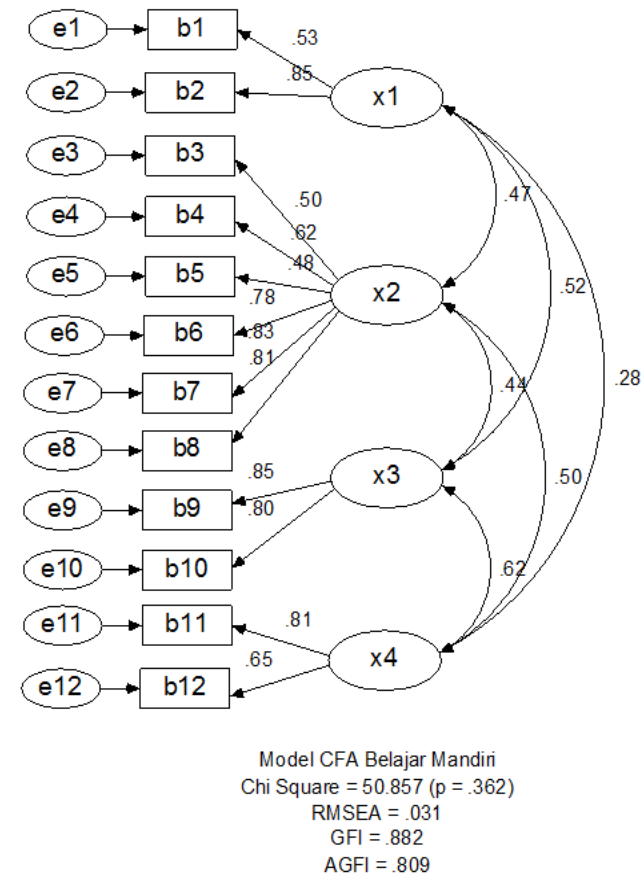

Gambar 4. Model CFA Kemandirian Mahasiswa dalam Belajar Hasil Uji Tahap 2

Hasil CFA kuesioner persepsi mahasiswa terhadap kualitas pengelolaan program tutorial tatap muka.

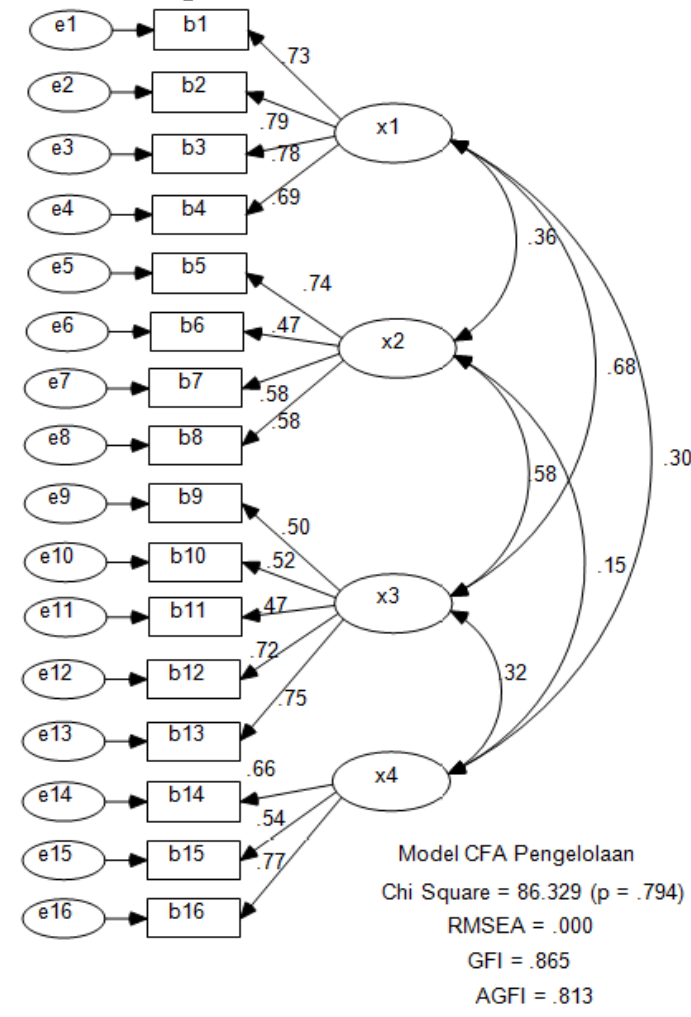

Gambar 5. Model CFA Persepsi Mahasiswa terhadap Pengelolaan Tutorial Hasil Uji Coba Tahap 2
Hasil CFA kemandirian mahasiswa dalam belajar

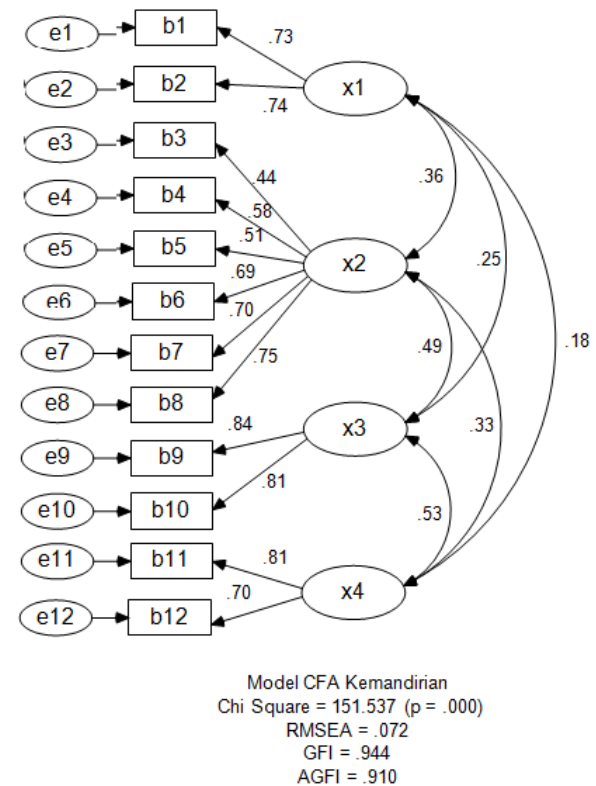

Gambar 6. Model CFA Kemandirian Mahasiswa dalam Belajar Hasil Uji Coba Tahap 3

Hasil CFA kuesioner persepsi mahasiswa terhadap pengelolaan program tutorial tatap muka adalah sebagai berikut tampak pada Gambar 15.

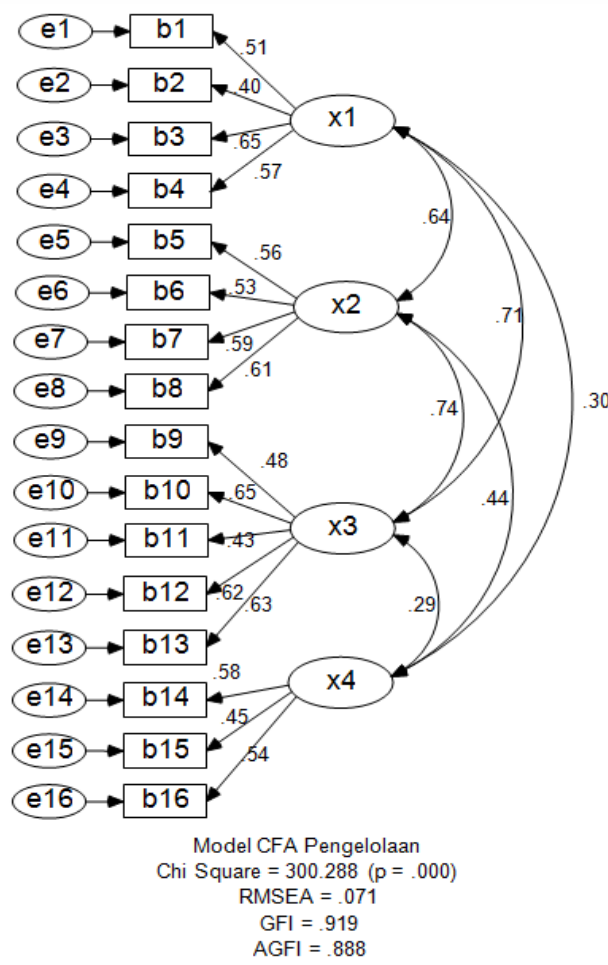

Gambar 7. Model CFA Persepsi Mahasiswa Terhadap Pengelolaan Program Tutorial Tatap Muka Hasil Uji Coba Tahap 3 
Berdasarkan indikator fit model (Ghozali \& Fuad, 2005, pp.29-32), hasil analisis CFA instrumen pengelolaan program tutorial dan kemandirian mahasiswa dalam belajar (Tabel 1 dan 2) menunjukkan bahwa kedua instrumen tersebut valid dan reliabel

Tabel 1. Hasil CFA Instrumen Persepsi Mahasiswa terhadap Pengelolaan Program Tutorial Tatap Muka Uji Coba Tahap 1, 2, dan 3.

\begin{tabular}{lccc}
\hline \multirow{2}{*}{ Indikator Fit } & \multicolumn{3}{c}{ Hasil Uji Coba Instrumen } \\
\cline { 2 - 4 } & Tahap 1 & Tahap 2 & Tahap 3 \\
\hline 1. Nilai Chi-Square dengan $\mathrm{p}>0,05$ & $106.516(\mathrm{p}=0,261)$ & $86.329(\mathrm{p}=0,794)$ & $300.288(\mathrm{p}=0,00)$ \\
2. GFI $>0,90$ & 0,883 & 0,865 & 0,919 \\
3. AGFI $>0,90$ & 0,838 & 0,813 & 0,888 \\
4. RMSEA $<0,1$ & 0,029 & 0,000 & 0,071 \\
\hline
\end{tabular}

Tabel 2. Hasil CFA Instrumen Kemandirian Mahasiswa dalam Belajar Mandiri Uji Coba Tahap 1, 2, dan 3 .

\begin{tabular}{lccc}
\hline \multirow{2}{*}{\multicolumn{1}{c}{ Indikator Fit }} & \multicolumn{3}{c}{ Hasil Uji Coba Instrumen } \\
\cline { 2 - 4 } & Tahap 1 & Tahap 2 & Tahap 3 \\
\hline 1. Nilai Chi-Square dengan $\mathrm{p}>0,05$ & $56.880(\mathrm{p}: 0,178)$ & $50.857(\mathrm{p}=0,362)$ & $151.537(\mathrm{p}=0,00)$ \\
2. GFI $>0,90$ & 0,904 & 0,882 & 0,944 \\
3. AGFI $>0,90$ & 0,844 & 0,809 & 0,910 \\
4. RMSEA $<0,1$ & 0,043 & 0,031 & 0,072 \\
\hline
\end{tabular}

Berdasarkan persyaratan analisis dan interpretasi hasil EFA (Hair et.al., 2010, pp.106-123), hasil analisis EFA untuk instrumen: Kualitas tempat/fasilitas tutorial, kualitas proses tutorial, dan kepuasan mahasiswa (Tabel 3-5) menunjukkan bahwa ketiga instrumen dinyatakan valid.

Tabel 3. Hasil EFA Instrumen Persepsi Mahasiswa terhadap Kualitas Tempat/Fasilitas Tutorial Tatap Muka Uji Coba Tahap 1, 2, dan 3.

\begin{tabular}{|c|c|c|c|}
\hline \multirow{2}{*}{ Persyaratan EFA } & \multicolumn{3}{|c|}{ Hasil Uji Coba Instrumen } \\
\hline & Tahap 1 & Tahap 2 & Tahap 3 \\
\hline Persyaratan analisis: & & & \\
\hline a. Hasil MSA > 0,5 & MSA: 0,591 & MSA: 0,656 & MSA: 0,684 \\
\hline b. $\alpha$ hasil uji Bartlett maksimal 0,05 & $\begin{array}{c}\alpha \text { hasil uji Bartlett }= \\
0,000\end{array}$ & $\begin{array}{l}\alpha \text { hasil uji Bartlett } \\
\quad=0,000\end{array}$ & $\begin{array}{l}\alpha \text { hasil uji Bartlett } \\
\quad=0,000\end{array}$ \\
\hline Persyaratan interpretasi: & & & \\
\hline $\begin{array}{l}\text { a. Nilai communalities setiap item > } \\
0,5\end{array}$ & $\begin{array}{l}\text { Communalities } \\
\text { terendah: } 0,505\end{array}$ & $\begin{array}{l}\text { Communalities } \\
\text { terendah: } 0,500\end{array}$ & $\begin{array}{l}\text { Communalities } \\
\text { terendah: } 0,555\end{array}$ \\
\hline b. Nilai eigenvalue minimal 1,00 & $\begin{array}{l}\text { Eigenvalue terendah: } \\
\qquad 1,911\end{array}$ & $\begin{array}{l}\text { Eigenvalue } \\
\text { terendah: } 1,937\end{array}$ & $\begin{array}{l}\text { Eigenvalue } \\
\text { terendah: } 1,928\end{array}$ \\
\hline $\begin{array}{l}\text { c. Total variance explained minimal } \\
60 \%\end{array}$ & $\begin{array}{l}\text { Total variance } \\
\text { explained: } 63,186 \%\end{array}$ & $\begin{array}{l}\text { Total variance } \\
\text { explained: } 67,128 \%\end{array}$ & $\begin{array}{l}\text { Total variance } \\
\text { explained: } 66,183 \%\end{array}$ \\
\hline $\begin{array}{l}\text { d. Loading factor setiap item } \\
\text { minimum 0,5 }\end{array}$ & $\begin{array}{l}\text { Loading factor } \\
\text { minimum: } 0,683\end{array}$ & $\begin{array}{l}\text { Loading factor } \\
\text { minimum: } 0,672\end{array}$ & $\begin{array}{l}\text { Loading factor } \\
\text { minimum: } 0,726\end{array}$ \\
\hline
\end{tabular}


Tabel 4. Hasil EFA Instrumen Persepsi Mahasiswa terhadap Kualitas Proses Tutorial Uji Coba Tahap 1, 2, dan 3.

\begin{tabular}{|c|c|c|c|}
\hline \multirow{2}{*}{ Analisis Faktor } & \multicolumn{3}{|c|}{ Hasil Uji Coba Instrumen } \\
\hline & Tahap 1 & Tahap 2 & Tahap 3 \\
\hline \multicolumn{4}{|l|}{ Persyaratan analisis: } \\
\hline Hasil MSA > 0,5 & MSA: 0,838 & MSA: 0,817 & MSA: 0,829 \\
\hline$\alpha$ hasil uji Bartlett maksimal 0,05 & $\alpha=0,000$ & $\alpha=0,000$ & $\alpha=0,000$ \\
\hline \multicolumn{4}{|l|}{ Persyaratan interpretasi: } \\
\hline Nilai communalities setiap item $>0,5$ & $\begin{array}{l}\text { Communalities } \\
\text { terendah: } 0,564\end{array}$ & $\begin{array}{l}\text { Communalities } \\
\text { terendah: } 0,544\end{array}$ & $\begin{array}{l}\text { Communalities } \\
\text { terendah: } 0,503\end{array}$ \\
\hline Nilai eigenvalue minimal 1,00 & $\begin{array}{l}\text { Eigenvalue terendah: } \\
\qquad 1,989\end{array}$ & $\begin{array}{l}\text { Eigenvalue terendah: } \\
\qquad 2,068\end{array}$ & $\begin{array}{l}\text { Eigenvalue terendah: } \\
\qquad 2,088\end{array}$ \\
\hline Total variance explained minimal $60 \%$ & $\begin{array}{l}\text { Total variance explained: } \\
\quad 69,982 \%\end{array}$ & $\begin{array}{l}\text { Total variance explained } \\
\qquad 70,112 \%\end{array}$ & $\begin{array}{l}\text { d:Total variance explained: } \\
68,899 \%\end{array}$ \\
\hline $\begin{array}{l}\text { Loading factor setiap item minimum } \\
0,5\end{array}$ & $\begin{array}{l}\text { Loading factor minimal: } \\
\qquad, 751\end{array}$ & $\begin{array}{l}\text { Loading factor } \\
\text { minimal: } 0,736\end{array}$ & $\begin{array}{l}\text { Loading factor minimal: } \\
\qquad 0,710\end{array}$ \\
\hline
\end{tabular}

Tabel 5. Hasil EFA Instrumen Kepuasan Mahasiswa terhadap Layanan Program Tutorial Tatap Muka Hasil Uji Coba Tahap 1, 2, dan 3.

\begin{tabular}{|c|c|c|c|}
\hline \multirow{2}{*}{ Analisis Faktor } & \multicolumn{3}{|c|}{ Hasil Uji Coba Instrumen } \\
\hline & Tahap 1 & Tahap 2 & Tahap 3 \\
\hline \multicolumn{4}{|l|}{ Persyaratan analisis: } \\
\hline Hasil MSA > 0,5 & MSA: 0,715 & MSA: 0,765 & MSA: 0,831 \\
\hline$\alpha$ hasil uji Bartlett maksimal 0,05 & $\alpha=0,000$ & $\alpha=0,000$ & $\alpha=0,000$ \\
\hline \multicolumn{4}{|l|}{ Persyaratan interpretasi: } \\
\hline Nilai communalities setiap item $>0,5$ & $\begin{array}{l}\text { Communalities } \\
\text { terendah: } 0,541\end{array}$ & $\begin{array}{l}\text { Communalities } \\
\text { terendah: } 0,668\end{array}$ & $\begin{array}{l}\text { Communalities } \\
\text { terendah: } 0,618\end{array}$ \\
\hline Nilai eigenvalue minimal 1,00 & $\begin{array}{l}\text { Eigenvalue terendah: } \\
\qquad 1,257\end{array}$ & $\begin{array}{l}\text { Eigenvalue terendah: } \\
\qquad 1,009\end{array}$ & $\begin{array}{l}\text { Eigenvalue terendah: } \\
\qquad 1,064\end{array}$ \\
\hline Total variance explained minimal 60\% & $\begin{array}{l}\text { Total variance explained: } \\
\quad 73,748 \%\end{array}$ & $\begin{array}{l}\text { Total variance explained: } \\
\qquad 82,625 \%\end{array}$ & $\begin{array}{l}\text { Total variance explained } \\
\qquad 73,483 \%\end{array}$ \\
\hline $\begin{array}{l}\text { Loading factor setiap item minimum } \\
0,5\end{array}$ & $\begin{array}{l}\text { Loading factor } \\
\text { terendah: } 0,564\end{array}$ & $\begin{array}{l}\text { Loading factor } \\
\text { terendah: } 0,742\end{array}$ & $\begin{array}{l}\text { Loading factor } \\
\text { terendah: } 0,737\end{array}$ \\
\hline
\end{tabular}

Hasil analisis reliabilitas terhadap tiga instrumen: Kualitas tempat/fasilitas tutorial, kualitas proses tutorial, dan Kepuasan mahasiswa (Tabel 6-8) menunjukkan bah- wa ketiga instrumen tersebut mempunyai nilai reliabilitas $>0,6$ sehingga dapat dinyatakan sebagai instrumen yang reliabel (Hair et.al., 2010, p.93). 
Tabel 6. Reliabilitas Persepsi Mahasiswa Terhadap Kualitas Tempat/Fasilitas Tutorial Hasil Uji Coba Tahap 1, 2, dan 3.

\begin{tabular}{|c|c|c|c|c|c|}
\hline \multirow{2}{*}{ No } & \multirow{2}{*}{ Dimensi } & \multirow{2}{*}{ Item } & \multicolumn{3}{|c|}{ Hasil Uji Reliabilitas } \\
\hline & & & Tahap 1 & Tahap 2 & Tahap 3 \\
\hline \multirow{2}{*}{1} & Persepsi mahasiswa & $1,2,3,4$ & 0,774 & 0,828 & 0,781 \\
\hline & terhadap tempat & & 0,733 & 0,776 & 0,802 \\
\hline 2 & $\begin{array}{l}\text { Persepsi mahasiswa } \\
\text { terhadap fasilitas }\end{array}$ & $5,6,7$ & 0,669 & 0,675 & 0,765 \\
\hline
\end{tabular}

Tabel 7. Reliabilitas Persepsi Mahasiswa Terhadap Kualitas Proses Tutorial Hasil Uji Coba Tahap 1, 2, dan 3.

\begin{tabular}{|c|c|c|c|c|c|}
\hline \multirow{2}{*}{ No } & \multirow{2}{*}{ Dimensi } & \multirow{2}{*}{ Item } & \multicolumn{3}{|c|}{ Hasil Uji Reliabilitas } \\
\hline & & & Tahap 1 & Tahap 2 & Tahap 3 \\
\hline \multirow{2}{*}{1} & Komitmen tutor dan & $1,2,3$ & 0,916 & 0,913 & 0,909 \\
\hline & mahasiswa & & 0,872 & 0,885 & 0,891 \\
\hline 2 & Kualitas proses tutorial & $4,5,6,7,8,9$ & 0,741 & 0,766 & 0,778 \\
\hline
\end{tabular}

Tabel 8. Reliabilitas Kepuasan Mahasiswa Terhadap Layanan Program Tutorial Tatap Muka Hasil Uji Coba Tahap 1, 2, dan 3.

\begin{tabular}{|c|c|c|c|c|c|c|}
\hline \multirow{2}{*}{ No } & \multirow{2}{*}{ Dimensi } & \multirow{2}{*}{ Item } & \multicolumn{4}{|c|}{ Hasil Uji Reliabilitas } \\
\hline & & & Tahap 1 & Tahap 2 & Tah & p 3 \\
\hline 1 & $\begin{array}{l}\text { Kepuasan mahasiswa terhadap } \\
\text { layanan petugas }\end{array}$ & $1,2,3,4$ & 0,851 & 0,892 & 0,849 & \\
\hline 2 & $\begin{array}{l}\text { Kepuasan mahasiswa terhadap } \\
\text { layanan bahan ajar }\end{array}$ & 5,6 & 0,873 & 0,902 & Drop & \\
\hline 3 & $\begin{array}{l}\text { Kepuasan mahasiswa terhadap } \\
\text { pengelolaan program }\end{array}$ & $7,8,9$ & $0,784 \quad 0,912$ & $0,874 \quad 0,961$ & 0,794 & 0,920 \\
\hline 4 & $\begin{array}{l}\text { Kepuasan mahasiswa terhadap } \\
\text { kualitas tutor }\end{array}$ & $10,11,12,13$ & 0,805 & 0,901 & 0,844 & \\
\hline 5 & $\begin{array}{l}\text { Kepuasan mahasiswa terhadap } \\
\text { tempat/fasilitas }\end{array}$ & $14,15,16$ & 0,750 & 0,788 & 0,823 & \\
\hline 6 & $\begin{array}{l}\text { Kepuasan mahasiswa terhadap } \\
\text { manfaat TTM }\end{array}$ & 17,18 & 0,871 & 0,892 & 0,905 & \\
\hline
\end{tabular}

Hasil uji coba model evaluasi P2HT untuk mengevaluasi program tutorial tatap muka UT pada 416 responden disajikan pada Tabel 9. 
Tabel 9. Hasil Uji Coba Model Evaluasi P2HT Pada Uji Coba Tahap 3.

\begin{tabular}{|c|c|c|c|}
\hline No. & Aspek yang Dievaluasi & Kriteria & Hasil Evaluasi \\
\hline 1. & $\begin{array}{l}\text { Persepsi mahasiswa terhadap } \\
\text { pengelolaan program tutorial }\end{array}$ & $\begin{array}{l}\text { Skor 29-32: baik. } \\
\text { Skor 20-28: cukup } \\
\text { Skor 16-19: kurang }\end{array}$ & $\begin{array}{l}\text { Baik }=60(14,42 \%) \\
\text { Cukup }=343 \text { orang }(82,45 \%) \\
\text { Kurang }=13 \text { orang }(3,13 \%)\end{array}$ \\
\hline 2. & Kemandirian mahasiswa dalam belajar & $\begin{array}{l}\text { Skor 40-48: tinggi } \\
\text { Skor 21-39: sedang } \\
\text { Skor 12-20: rendah }\end{array}$ & $\begin{array}{l}\text { Tinggi }=63 \text { orang }(15,14 \%) \\
\text { Sedang }=350 \text { orang }(84,13 \%) \\
\text { Rendah }=3(0,83 \%)\end{array}$ \\
\hline 3. & $\begin{array}{l}\text { Persepsi mahasiswa terhadap kualitas } \\
\text { tempat/fasilitas tutorial }\end{array}$ & $\begin{array}{l}\text { Skor } 23 \text { - 28: baik } \\
\text { Skor } 13 \text { - 22: sedang } \\
\text { Skor } 7 \text { - 12: kurang }\end{array}$ & $\begin{array}{l}\text { Baik }=147 \text { orang }(35,34 \%) \\
\text { Cukup }=269 \text { orang }(64,66 \%) \\
\text { Kurang baik }=0\end{array}$ \\
\hline 4. & $\begin{array}{l}\text { Persepsi mahasiswa terhadap kualitas } \\
\text { proses tutorial }\end{array}$ & $\begin{array}{l}\text { Skor 29-36: baik } \\
\text { Skor 16-28: sedang } \\
\text { Skor 9-15: sedang }\end{array}$ & $\begin{array}{l}\text { Tinggi }=231 \text { orang }(55,53 \%) \\
\text { Sedang }=292 \text { orang }(44,47 \%) \\
\text { Rendah }=0\end{array}$ \\
\hline 5. & $\begin{array}{l}\text { Kepuasan mahasiswa terhadap layanan } \\
\text { program tutorial }\end{array}$ & $\begin{array}{l}\text { Skor 16-28: rendah } \\
\text { Skor 29-51: sedang } \\
\text { Skor 52-64: tinggi }\end{array}$ & $\begin{array}{l}\text { Tinggi }=150 \text { orang }(36,06 \%) \\
\text { Sedang }=266 \text { orang }(63,94 \%) \\
\text { Rendah }=0\end{array}$ \\
\hline 6. & Hasil belajar mahasiswa & $\begin{array}{l}\text { Nilai mata kuliah yang } \\
\text { diikuti tutorialnya } \\
\text { minimal C. }\end{array}$ & $\begin{array}{l}A=85 \text { orang }(20,43 \%) \\
B=260 \text { orang }(62,50 \%) \\
C=70 \text { orang }(16,83 \%) \\
D=1 \text { orang }(0,24 \%)\end{array}$ \\
\hline
\end{tabular}

Hasil evaluasi kemandirian mahasiswa dalam belajar pada uji coba tahap 3 (Tabel 9) menunjukkan bahwa sebagian besar mahasiswa $(84,13 \%)$ mempunyai tingkat kemandirian belajar dalam kategori sedang. Hasil tersebut menunjukkan bahwa belajar mandiri masih menjadi masalah bagi mahasiswa UT. Hasil ini sesuai dengan temuan Wardani (2000), Kadarko (2000), Adji (2009) bahwa mahasiswa UT masih mengalami masalah dalam belajar mandiri. Idealnya mahasiswa yang belajar dengan sistem pendidikan jarak jauh memiliki kemandirian belajar yang tinggi karena sistem pendidikan jarak jauh mempersyaratkan hal tersebut (Suparman dan Zuhairi, 2009, p.22). Menurut Subagja (2001, pp.245-246) kurangnya kemandirian mahasiswa UT dalam belajar berhubungan dengan kebiasaan atau budaya belajar yang selama ini dilakukan oleh mahasiswa. Budaya belajar di Indonesia belum mendukung tumbuhnya belajar mandiri. Hal ini terkait dengan sistem pembelajaran formal yang selama ini banyak terjadi di Indonesia yaitu belajar tatap muka. Karena belajar mandiri masih men- jadi masalah bagi mahasiswa UT maka keputusan mahasiswa untuk mengikuti program tutorial tatap muka merupakan keputusan yang tepat.

Informasi tentang kemandirian mahasiswa dalam belajar sangat diperlukan oleh tutor untuk menentukan strategi tutorial yang tepat agar proses tutorial dapat berlangsung secara efektif. Menurut Grow (1991) peran guru yang tepat untuk kelompok murid dengan tingkat kemandirian sedang (moderate self-direction) dan menengah (intermediate self-direction) adalah sebagai moderator, fasilitator, dan pembimbing. Hasil evaluasi terhadap kualitas proses tutorial (Tabel 9) menunjukkan bahwa 44,47\% mahasiswa mempersepsikan bahwa kualitas proses tutorial masih dalam kategori sedang. Hasil ini menunjukkan bahwa proses tutorial belum mampu memfasilitasi mahasiswa secara baik dalam mengkonstruksi pengetahuan (Reigeluth \& Carr-Chellman (2009, p.6) dan dalam mengembangkan cognitive skills, knowledge, and learning skills (Ormond, 2000, pp.6-7). 
Sebagai penyelenggara program tutorial tatap muka, UPBJJ-UT perlu terus berupaya meningkatkan kualitas pengelolaan progam tutorial tatap muka dan penyediaan tempat/fasilitas tutorial yang lebih baik agar kepuasan mahasiswa terhadap layanan program tutorial dapat meningkat. Hasil penelitian ini menunjukkan bahwa sebagian besar mahasiswa (63,94\%) mempunyai tingkat kepuasan sedang dan hanya 36,06\% mahasiswa yang mempunyai tingkat kepuasan tinggi. Hal ini menunjukkan bahwa program tutorial tatap muka yang dilaksanakan UPBJJ-UT belum dapat memenuhi semua kebutuhan belajar mahasiswa (Gerson, 1993, p.5). Untuk memenuhi kebutuhan belajar mahasiswa, UPBJJ-UT perlu melakukan need assessment (Kirkpatrick \& Kirkpatrick, 2006, p.3).

Model empiris evaluasi P2HT diperoleh dari hasil uji coba tahap 3 yang dianalisis dengan menggunakan analisis jalur tampak pada bagan 2 berikut.

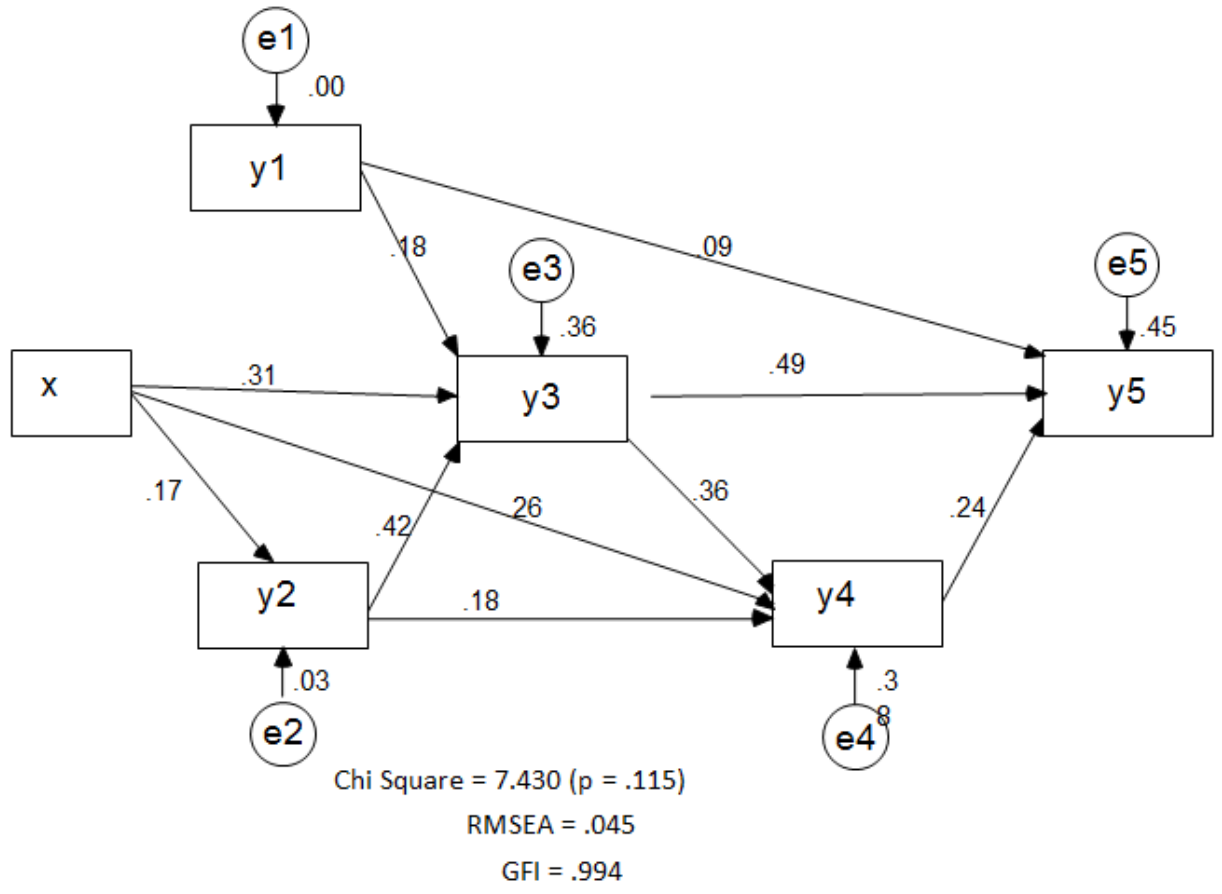

Gambar 8. Bagan Model Empiris Evaluasi P2HT.

Model empiris (Gambar Bagan 8) yang diperoleh dari hasil analisis jalur memenuhi syarat sebagai model yang fit (Ghozali \& Fuad, 2005, pp.29-32). Model empiris sedikit berbeda dengan model konseptualnya (Gambar Bagan 1). Hasil analisis jalur menunjukkan tidak ada pengaruh yang signifikan antara pengelolaan program (X) dengan kemandirian mahasiswa dalam belajar $\left(\mathrm{Y}_{1}\right)$. Tidak adanya pengaruh yang signifikan antara pengelolaan program dengan kemandirian mahasiswa dalam belajar kemungkinan disebabkan oleh kualitas dan atau kuantitas support system yang disediakan oleh pengelola program tutorial belum dapat merangsang untuk meningkatnya kemandirian mahasiswa dalam belajar. Me- nurut Melton (2002, p.110) ada dua bentuk dukungan (support) yang harus diberikan kepada peserta didik pendidikan jarak jauh agar mereka dapat menyelesaikan studinya dengan baik. Kedua bentuk support tersebut adalah tersedianya bahan ajar mandiri (selfstudy materials) untuk membantu agar peserta didik dapat belajar sendiri dan tersedianya layanan bantuan belajar (student support) yang dibutuhkan pada saat mereka menemui kesulitan dalam mempelajari bahan ajar. Lebih lanjut, dinyatakan bahwa layanan bantuan belajar harus didisain untuk dapat memenuhi kebutuhan individu peserta di-dik yang dapat dilakukan dengan menyedia-kan tutor (mentor), konselor, dan center-based staff (staf akademik, pustaka- 
wan, dan tenaga ICT). Fakta di lapangan menunjukkan bahwa layanan dan fasilitas untuk memenuhi kebutuhan individual mahasiswa masih sangat terbatas.

Hasil analisis statistik menunjukkan bahwa kemandirian mempunyai pengaruh yang signifikan $(p<0,05)$ terhadap hasil belajar. Hasil penelitian ini sesuai dengan hasil penelitian Darmayanti (1993), Islam (2000), dan Tahar \& Enceng (2006) yang menemukan adanya korelasi positif antara kemandirian mahasiswa dalam belajar dengan hasil belajar. Kemandirian mahasiswa dalam belajar memberikan efek total (standardized total effects) terhadap hasil belajar sebesar 0,194 yang diperoleh dari efek langsung sebesar 0,091 dan efek tidak langsung sebesar 0,103. Pengelolaan program tutorial dan kualitas tempat/fasilitas tutorial perlu mendapat perhatian serius dari UPBJJ karena kedua aspek tersebut berpengaruh terhadap kepuasan mahasiswa terhadap layanan program tutorial dengan total pengaruh masing-masing sebesar 0,429 dan 0,333 . Sebagai penyelenggara program tutorial tatap muka, UPBJJ-UT perlu terus berupaya meningkatkan kualitas pengelolaan progam tutorial tatap muka dan penyediaan tempat/fasilitas tutorial yang lebih baik agar kepuasan mahasiswa terhadap layanan program tutorial dapat meningkat. Hasil penelitian ini menunjukkan bahwa sebagian besar mahasiswa $(63,94 \%)$ mempunyai tingkat kepuasan sedang dan hanya $36,06 \%$ mahasiswa yang mempunyai tingkat kepuasan tinggi terhadap layanan program tutorial tatap muka yang diberikan UPBJJ-UT. Hasil ini menunjukkan bahwa program tutorial tatap muka yang dilaksanakan UPBJJ-UT baru dapat memenuhi sebagian kebutuhan belajar mahasiswa (Gerson, 1993, p.5). Dari hasil analisis jalur ternyata proses tutorial $\left(\mathrm{Y}_{3}\right)$ mempunyai pengaruh yang paling besar terhadap hasil belajar mahasiswa. Hasil analisis tersebut menunjukkan bahwa proses tutorial memberikan efek total (standardired total effects) sebesar 0,580 yang diperoleh dari efek langsung sebesar 0,492 dan efek tidak langsung sebesar 0,088. Arti dari temuan ini adalah setiap ada perubahan sebesar satu unit pada variabel proses tutorial akan memberikan pengaruh sebesar 0,580 terhadap variabel hasil belajar mahasiswa. Hasil analisis ini menunjukkan bahwa proses tutorial efektif untuk meningkatkan hasil belajar mahasiswa UT.

\section{Simpulan}

Berdasarkan hasil kajian, pengembangan, uji coba, dan analisis data tentang model evaluasi P2HT dapat ditarik beberapa simpulan sebagai berikut:

Pertama, model evaluasi P2HT merupakan model evaluasi program tutorial tatap muka UT yang menekankan pada evaluasi komponen perencanaan, pelaksanaan, dan hasil program. Evaluasi komponen perencanaan difokuskan pada aspek: (1) pengelolaan program, (2) tingkat kemandirian mahasiswa dalam belajar, dan (3) tempat/fasilitas tutorial. Evaluasi pelaksanaan difokuskan pada aspek kualitas proses tutorial. Evaluasi hasil difokuskan pada aspek kepuasan dan hasil belajar mahasiswa. Model P2HT dilengkapi dengan perangkat model yang terdiri dari: (1) Pedoman penyelenggaraan evaluasi, (2) Instrumen, dan (3) Format pelaporan hasil evaluasi. Model evaluasi P2HT terbukti merupakan model evaluasi yang tepat, komprehensif, praktis, dan mudah digunakan.

Kedua, model empiris yang dihasilkan dalam penelitian ini menunjukkan bahwa pengelolaan program tidak berpengaruh secara signifikan terhadap kemandirian mahasiswa dalam belajar. Pengelolaan program, kemandirian mahasiswa dalam belajar, tempat/fasilitas tutorial, proses tutorial, dan kepuasan mahasiswa berpengaruh terhadap hasil belajar mahasiswa. Proses tutorial memberikan total pengaruh paling besar $(0,58)$ disusul oleh pengelolaan program $(0,30)$, tempat/fasilitas tutorial $(0,29)$, kepuasan mahasiswa $(0,24)$, dan kemandirian mahasiswa dalam belajar $(0,20)$.

Ketiga, berdasarkan penilaian para ahli dan praktisi pendidikan jarak jauh, pedoman penyelenggaraan evaluasi program tutorial tatap muka UT merupakan pedo- 
man yang jelas, mudah dipahami, komunikatif, dan mudah digunakan.

Keempat, berdasarkan hasil penilaian para ahli dan praktisi serta hasil uji statistik, instrumen-instrumen yang dikembangkan dalam penelitian ini merupakan instrumen yang dapat menghasilkan hasil pengukuran yang valid dan reliabel.

Kelima, berdasarkan penilaian para ahli dan praktisi pendidikan jarak jauh, format pelaporan hasil evaluasi program tutorial tatap muka mempunyai petunjuk yang jelas, bahasa yang digunakan komunikatif dan mudah dimengerti, dan mudah digunakan.

\section{Daftar Pustaka}

Adji, Sandra Sukmaning. (2009). Analisis kepuasan mahasiswa pada kegiatan tutorial tatap muka mata kuliah praktikum IP A SD. Hasil penelitian, tidak diterbitkan, Universitas Terbuka, Jakarta.

Amini, Mukti., Mardiana, Ade., \& Hanafi. (2009). Efektivitas pelaksanaan pembimbingan mata kuliah peningkatan kemampuan mengajar program S1 PGPAUD Universitas Terbuka. Hasil penelitian, tidak diterbitkan, Universitas Terbuka, Jakarta.

Belawati, Tian. (1997). Understanding and increasing student persistance in distance education: A case of Indonesia. Jurnal Studi Indonesia 7 (1). 29-46.

Chandrawati, Titi., Tatminingsih, Sri, \& Budiastra, Ketut. (2009). Efektivitas pelaksanaan pembimbingan mata kuliah peningkatan kemampuan profesional program S1 PGPAUD Universitas Terbuka. Hasil penelitian, tidak diterbitkan, Universitas Terbuka, Jakarta.

Darmayanti, Tri. (1993). Readiness for selfdirected learning and achivement of the students of Universitas Terbuka. Tesis master, tidak diterbitkan, University of Victoria, Victoria, BC.

Depdikbud. (2012). Peraturan Menteri Pendidikan dan Kebudayaan Nomor: 24 Tabun
2012 tentang penyelenggaraan pendidikan jarak, jauh pada perguruan tinggi.

Dick, W., Carey, L., \& Carey, J.O. (2005). The systematic design of instruction $\left(6^{\text {th }}\right.$ ed.). Boston: Pearson.

Fitzpatrick, J.L., Sanders, J.R. \& Worthen, B.R. (2004). Program evaluation: Alternative approaches and practical guidelines $\left(3^{\text {rd }}\right.$ ed.). Boston: Pearson.

Gall, M.D., Gall, J.P. \& Borg, W.R. (2003). Educational research: An introduction. Boston: Pearson Education. Inc.

Gerson, R.,F. (1993). Mengukur kepuasan pelanggan (Terjemahan Hesty Widyaningrum). New York: Crisp Publications, Inc.

Ghozali, Imam \& Fuad (2005). Strcture equation modelling: teori, konsep dan aplikasi dengan program lisrel 8.54. Semarang: Badan Penerbit Universitas Diponegoro Semarang.

Grow, G. (1991). Teaching learners to be selfdirected. Diambil tanggal 11 Januari 2013 dari http://www.longleaf.net/ ggrow/SSDL/model.html.

Hair J.F., Black, W.C., Babin, B.J., et.al. (2010). Multivariate data analisys. New York: Pearson Prentice Hall.

Holmberg, B. (2005). Theory and practice of distance education. New York: Taylor \& Francis e-Library.

Islam, Samsul. (2000). Prestasi belajar, kesiapan belajar mandiri dan konsep diri mahasiswa pada sistem pendidikan terbuka dan jarak jauh: Suatu studi korelasional di Universitas Terbuka. Tesis magister, tidak diterbitkan, Universitas Negeri Jakarta, Jakarta.

Johnson, R.A., Kast, F.E., \& Rosenzweig, J.E. (1973). The theory and management of systems. Tokyo: McGraw-Hill Kogakusha.Ltd.

Kadarko, Wahyuni. (2000). Kemampuan belajar mandiri dan faktor-faktor psikososial yang mempengaruhinya: Kasus Universitas Terbuka. Jurnal Pendidikan Terbuka dan Jarak Jauh, vol 1 (1). 
Kaufman, R. \& Thomas, S. (1980). Evaluation without fear. New York: New Viewpoints.

Kirkpatrick, D,L. \& Kirkpatrick, J.D. (2006). Evaluating training programs: $\backslash$ the four levels $3^{\text {rd }}$ ed. San Francisco: Berret-Koehler Publishers, Inc.

Long, D., G. (1990). Learner managed learning. London: Kogan Page.

Mahasiswa UT dituntut belajar mandiri. (4 November 2010). Kedaulatan Rakyat, hal. 18.

Melton, R.F. (2002). Planning and developing open and distance Learning: A quality assurance approach. London: Routledge Falmer.

Nunnally, J., C. (1978). Psychometric theory $\left(2^{\text {nd }}\right.$ ed.). New York: McGraw-Hill Book Company.

Ormond, S. (2000). Supporting students in open and distance learning. London: Kogan Page Limited.

Panagiotis, A. \& Chrysoula, I. (2010). Communication between tutors-student in DL: A case study of the Hellenic Open University. European Journal of Open, Distance, and E-learning. Diambil pada tanggal 15 November 2010 dari http://www.eurodl.org/ materials/contrib/2010/Panagiotis_ Chrysoula.pdf

Peffers, et.al. (2007). A design science research methodology for information systems research. Journal of Management Information Systems, vol. 24 issue 3, winter 2007-8, pp. 45-78.

Reigeluth, C.M. \& Carr-Chellman, A.A. (2009). Instructional design theories and models vol III. New York: Taylor and Francis, Publishers.

Samarawikrama, R.,G. (2005). Determinants of student readiness for flexible learning: Some preliminary findings. Distance Education. Melbourne: May 2005, vol. 26: 48-67.

Sarwono, Jonathan. (2012). Path analysis: Teori, prosedur analisis untuk riset skripsi, tesis dan disertasi (menggunakan SPSS). Jakarta: PT Elex Media Komputindo.

Subagja. (2001). Pelembagaan upaya pengendalian mutuakademik di pergu- ruan tinggi. Dalam Pannen, dkk. (Ed.). Cakrawala Pendidikan. Jakarta: Pusat Penerbitan Universitas Terbuka

Sudilah, Astuti., Diah., \& Zuhriyah, Siti. (2009). Studi tentang pengelolaan tutorial tatap muka (TTM) mahasiswa program pendidikan dasar (pendas) di UPBJJ-UT Yogyakarta. Hasil penelitian, tidak diterbitkan, Universitas Terbuka, Jakarta.

Suharno, Supoyo, \& Suparno. (2009). Kajian faktor-faktor pelaksanaan program tutorial mahasiswa S1 PGSD UPBJJUT Bandar Lampung. Hasil penelitian, tidak diterbitkan, Universitas Terbuka, Jakarta.

Suparman, Atwi \& Zuhairi, Aminudin. (2009). Pendidikan jarak jaub: Teori dan praktek. Jakarta: Pusat Penerbitan Universitas Terbuka.

Tahar, Irsan \& Enceng (2006). Hubungan kemandirian dan hasil belajar pada pendidikan jarak jauh. Jurnal Pendidikan Terbuka dan Jarak Jauh, vol. 7 (2).

Wardani, I.G.A.K.. (2000). Program tutorial dalam sistem pendidikan tinggi terbuka dan jarak jauh. Jurnal Pendidikan Terbuka dan Jarak Jauh, vol. 1 (2).

Zhang, S. and Fulford, C. P. (1994), "Are interaction time and psychological interactivity the same thing in the distance learning television room?" Education Technology, vol. 34, no. 6, pp. 58-64.

Zirkle, C. (2004). Access barriers experienced by adults in distance education courses and programms: A review of the research literature. Midwest Research-to Practice Conference in Adult, Continuing, and Community Education. Diambil pada tanggal 18 November 2010 dari: https://scho larworks.ipui.edu/bitsream/handle/ 1805/273/zirkle.pdf? sequence $=1$.

Zirkin, B. G. and Sumler, D. E. (1995), "Interactive or non-interactive? that is the question!!! an annotated bibliography." Journal of Distance Education, vol. 10, No. 1, pp. 95-112. 